\title{
PENGUATAN HAK BERDAULAT (SOUVEREIGN RIGHT) PADA ZEE INDONESIA DALAM RANGKA PERLINDUNGAN SUMBER DAYA ALAM LAUT
}

\author{
Indien Winarwati \\ Fakultas Hukum Universitas Trunojoyo Madura \\ Jl. Raya Telang, Kec. Kamal, Bangkalan \\ Email: Indien_w@yahoo.com
}

\begin{abstract}
Sea is a important region for the integrity and unifying, a means of defense and security and foremost as a means of prosperity and welfare of a country due to the potential of the marine resources. Geographically, Indonesia can be termed as a maritime nation. Indonesia has the largest sea area in the world where two-thirds of its territory is waters. Indonesian Exclusive Economic Zone (EEZ) is a maritime area that has the greatest wealth potential. To Regulate, protect and enforce the law in the EEZ, the Indonesian government enacted Law No. 5 of 1983 on the Indonesian Exclusive Economic Zone. In that regulation, there is a provision on the sovereign rights as contained in the provisions of UNCLOS (United Nations Convention on the Law of the Sea). Such right is a privilege rights to carry out the exploration, exploitation and conservation of marine resources. To that end, these rights should be used optimally in order to utilize and protect marine resources from illegal fishing by foreign vessels that have been so frequent that it can be utilized for the welfare and prosperity of society.
\end{abstract}

\section{Keywords: Indonesian Sea, Sovereign Rights, Indonesian Exclusive Economic Zone, Protection of Marine Resources}

\begin{abstract}
Abstrak
Laut merupakan wilayah yang sangat penting bagi keutuhan dan pemersatu, sarana pertahanan dan keamanan serta yang paling utama sebagai sarana kemakmuran dan kesejahteraan sebuah negara karena adanya potensi sumber daya laut tersebut. Secara geografis Indonesia dapat disebut sebagai negara maritim. Indonesia memiliki wilayah laut terbesar di dunia dimana dua pertiga wilayahnya merupakan perairan. Zona Ekonomi Eksklusif (ZEE) Indonesia merupakan wilayah laut yang memiliki potensi kekayaan terbesar. untuk mengatur, melindungi dan melakukan penegakan hukum di ZEE tersebut, pemerintahan Indonesia memberlakukan Undang-Undang No 5 Tahun 1983 tentang Zona Ekonomi Eksklusif Indonesia. Di dalam peraturan tersebut, terdapat ketentuan tentang hak berdaulat (souvereign right) sebagaimana yang terdapat dalam ketentuan UNCLOS (United Nations Convention On The Law Of The Sea). Hak tersebut merupakan hak istimewa untuk melakukan eskplorasi, eksploitasi dan konservasi terhadap sumber daya lautnya. Untuk itu, hak tersebut hendaknya dapat digunakan secara optimal dalam rangka memanfaatkan sekaligus melindungi sumberdaya laut dari pencurian ikan oleh kapal-kapal asing yang selama ini sering terjadi sehingga dapat dimanfaatkan untuk kesejahteraan dan kemakmuran masyarakat.
\end{abstract}

\section{Kata kunci: Laut Indonesia, Hak Berdaulat, Zona Ekonomi Eksklusif Indonesia, Perlindungan SDA laut}




\section{A. Pendahuluan}

Indonesia memiliki wilayah laut terbesar di dunia dan dua pertiga dari wilayahnya merupakan wilayah perairan. Berdasarkan fakta tersebut, maka secara geografis Indonesia dapat disebut sebagai negara maritim, yang memiliki luas laut sebesar 3,2 juta $\mathrm{km}^{2}$ yang terdiri dari laut teritorial dengan luas 0.3 juta $\mathrm{km} 2$, laut kepulauan 2.9 juta $\mathrm{km} 2$ dan zona ekonomi eksklusif 2.7 juta km2. Pada saat Indonesia diproklamasikan sebagai negara yang merdeka pada tanggal 17 Agustus 1945, Indonesia merupakan negara yang terdiri atas beribu pulau yang tersebar dari Sabang sampai Merauke dan disebut sebagai negara kepulauan. Indonesia memiliki pulau sebanyak 17.508 pulau dan garis pantai sepanjang $95.181 \mathrm{~km}$.

Laut merupakan wilayah yang sangat penting bagi keutuhan dan pemersatu sebuah negara, sarana pertahanan dan keamanan dan yang paling utama adalah sarana kemakmuran dan kesejahteraan negara karena adanya potensi sumber daya lauit tersebut. Laut Indonesia menyimpan potensi kekayaan yang sangat besar.

Zona Ekonomi Eksklusif (ZEE) Indonesia merupakan wilayah laut yang memiliki potensi kekayaan terbesar bagi Indonesia. Pentingnya potensi-potensi sumber kekayaan di laut ini, pemerintah telah mengeluarkan berbagai jenis produk hukum dalam mengatur, melindungi dan melakukan penegakan hukum di ZEE yaitu Undang-Undang No 5 Tahun 1983 tentang Zona Ekonomi Eksklusif Indonesia.

Berkaitan dengan ketentuan dalam ZEE, terdapat ketentuan tentang hak berdaulat (souvereign right) sebagaimana yang terdapat dalam ketentuan Hukum Laut yaitu UNCLOS ( United Nations Convention On The Law Of The Sea) yang menyatakan bahwa negara pantai memiliki hak berdaulat yaitu hak istimewa untuk mengeskplorasi, mengeksploitasi dan konservasi sumber daya alam lautnya. Hal inipun telah di atur dalam ketentuan ZEE Indonesia, sebagaimana yang terdapat pada pasal 2 UU No. 5 tahun 1983, yang menetapkan bahwa. "ZEE Indonesia adalah jalur di luar dan berbatasan dengan laut wilayah Indonesia sebagaimana ditetapkan berdasarkan undang-undang yang berlaku tentang perairan Indonesia yang meliputi dasar laut, tanah dibawahnya dan air diatasnya dengan batas terluar 200 (dua ratus) mil laut diukur dari garis pangkal laut wilayah. Selanjutnya pada pasal 4 dinyatakan bahwa Hak berdaulat untuk keperluan eksplorasi dan eksploitasi, konservasi dan pengelolaan sumber kekayaan alam, baik hayati maupun non-hayati.

Berkaitan dengan hak berdaulat tersebut hendaknya dapat digunakan secara optimal dalam rangka memanfaatkan sekaligus melindungi sumberdaya laut dan terhindar dari pencurrian ikan dari kapal-kapal asing, sebagaimana diketahui bahwa selama ini sumberdaya laut Indonesia di ZEE seringkali diambil secara ilegal oleh kapal negara lain, maka dengan mengoptimalkan hak berdaulat tersebut, Indonesia dapat memanfaatkan dan menikmati sumberdaya laut untuk kesejahteraan masyarakat.

\section{B. Pembahasan}

\section{Konsep Zona Ekonomi Eksklusif (ZEE)}


Perkembangan konsepsi zona ekonomi eksklusif (exclusive economic zone) dimulai dari adanya Proklamasi Presiden Truman tahun 1945 mengenai perikanan, yang mengakui hakhak dari negara lain untuk membentuk kawasan laut di luar pantai negara mereka. ${ }^{1}$ Proklamasi Truman tentang perikanan tersebut menentukan bahwa perairan tempat pembentukan zona konservasi tetap merupakan laut lepas. Isi Proklamasi Truman tersebut adalah :

"In view of the pressing need for conservation and protection of fishery resources, the Government of the United States regards it as proper to establish conservation zones in those areas of the high seae contigous to the coasts of the United States where in fishing activities have been or in the future may be develop and maintained on a substantial scale;

Where such activities have been or shall hereafter be developed and maintanedy its nationals alone, the United States regards it as proper to establish explitly bounded conservation zones in which fishing activities shall be subject to the regulation and control of the United States;

Where such activities have been or shall hereafter be legitimately developed and maintained jointly by nationals of the United States and nationals of other states, explicitly bounded conservaiton zones may be established under agreement between the United States and such other states; and all fishing activities in such zones shall be subject to regulation and control as provided in such agreements. "2

Pertimbangan yang mendorong Pemerintah Amerika Serikat mengambil tindakan yang inti pokoknya dituangkan dalam proklamasi di atas adalah bahwa perikanan sangat penting sebagai sumber kehidupan bagi masyarakat yang hidup di daerah pantai dan penting pula sebagai sumber bahan bagi industri makanan Amerika Serikat.

Selain itu meningkatnya kemajuan dalam peralatan dan teknik penangkapan ikan menimbulkan bahaya penangkapan yang berlebihan (over fishing), sehingga mengakibatkan terkuranginya sumber kekayaan ikan. Hal ini menimbulkan kebutuhan yang mendesak untuk melindungi sumber perikanan pantai dari cara-cara pengambilan yang mengancam kelangsungan sumber kekayaan. Sedangkan pengaturan pengambilan kekayaan hayati yang ada waktu itu hanya berupa perjanjian-perjanjian perikanan antara negara yang berkepentingan dan dinilai tidak memadai sebagai tindakan untuk melindungi dan menjamin kelangsungan hidup dari sumber kekayaan hayati tersebut. Berkaitan dengan kebutuhan yang mendesak untuk melindungi sumber perikanan pantai, maka Pemerintah Amerika Serikat menganggap perlu mengambil kebijaksanaan untuk melakukan pencadangan (conservation) dan perlindungan (protection) kekayaan hayati yang terdapat di laut yang berbatasan dengan pantainya.

1 Chairul Anwar, Zona Ekonomi Eksklusif, Dalam Hukum Internasional, Cet pertama, Sinar Grafika, Jakarta, 1995, hlm. 5

2 Truman Proclamation On Coastal Fisheries, Proclamation No. 2668, "Policy of the United States with Respect to Coastal Fisheries In Certain Areas of The High Seas", Sept. 28, 1945, 10 Fed. Reg. 12304: 3CFR, 1943-1948 Comp, p. 68 : XIII Buletin, Departemen of State, No 327, Sept, 30, 1945, hlm. 484 Dalam S Houston Lay, Robin Churchill, Myron Nordquist, New Direction In The Law of The Sea, Document-Vol. I, Oceana Publication, Dobbs Ferry, New York, 1973, hlm. 98 
Inti pokok dari kebijaksanaan perlindungan perikanan yang termuat dalam Proklamasi Truman tahun 1945 adalah bahwa kegiatan perikanan di laut yang selama ini hanya dilakukan oleh warganya, sudah sepatutnya apabila ditetapkan daerah-daerah perlindungan perikanan yang menjadikan kegiatan perikanan tersebut seluruhnya di bawah pengaturan Amerika Serikat. Untuk menjamin daerah perikanan yang telah dilakukan dan dikembangkan oleh nelayan-nelayan asing, maka Amerika Serikat dan negara asing yang bersangkutan dapat menetapkan daerah perlindungan perikanan secara bersama melalui suatu perjanjian. Amerika Serikat mengakui hak negara lain untuk mengadakan daerah-daerah perlindungan perikanan serupa, tetapi hak atas kegiatan perikanan warganegara Amerika Serikat yang telah ada sebelumnya tetap diakui. ${ }^{3}$

Adanya Proklamasi Truman tentang perikanan tersebut, negara-negara Amerika Latin yaitu Chile, Ekuador dan Peru memberikan reaksinya dan mengajukan suatu klaim 200 mil zona laut melalui penandatanganan Deklarasi Santiago tahun 1952. Tujuan dari Deklarasi tersebut pada pokoknya adalah keinginan negara untuk memelihara dan menyediakan bagi rakyatnya sumber daya alam dari kawasan laut yang bersambungan dengan pantai negaranya. ${ }^{4}$ Konsepsi zona laut yang terdapat dalam Deklarasi tersebut merupakan elemen-elemen dari zona ekonomi eksklusif yang diperkenalkan pertama kalinya. Elemen-elemen tersebut mengatur klaim atas seluruh sumber daya alam dan hak eksklusif untuk melakukan eksplorasi, konservasi dan eksploitasi atas kawasan laut sejauh 200 mil dari pantai. ${ }^{5}$

\section{ZEE Dalam Peraturan Hukum Laut (UNCLOS)}

Berkaitan dengan konsepsi zona ekonomi eksklusif tersebut, konferensi Hukum Laut ke I dan II telah gagal menentukan batas zona perikanan. Baru pada konferensi Hukum Laut III, zona ekonomi eksklusif diatur dan merupakan suatu rezim tersendiri, yaitu adanya hak-hak dan yurisdiksi dari negara pantai untuk melakukan tindakan tertentu di zona ekonomi eksklusif. Pengaturan tentang hak-hak dan yurisdiksi dari negara pantai tersebut merupakan suatu pengaturan baru dan menimbulkan perubahan mendasar bagi hukum laut, dimana terjadi pemisahan pada laut teritorial yang merupakan zona kedaulatan negara pantai dan laut lepas yang terbuka untuk semua negara. Negara pantai walaupun diberikan hak-hak dan yurisdiksi dalam zona laut seluas 200 mil, keadaan ini tidak mengubah status hukum dari zona laut tersebut sebagai laut lepas. Zona ekonomi eksklusif merupakan suatu daerah atau area yang terletak di luar dan berdampingan dengan laut teritorial. Ini menunjukkan bahwa zona ekonomi eksklusif berada di luar wilayah negara atau bukan merupakan wilayah negara, tetapi negara pantai yang bersangkutan memiliki hak-hak dan yurisdiksi-yurisdiksi tertentu. ${ }^{6}$ Namun demikian, pada zona ekonomi eksklusif tersebut hak-hak dan kebebasan-kebebasan yang dimiliki oleh negara lain juga diakui.

Mengacu pada pasal 55 UNCLOS, yang disebut zona ekonomi eksklusif adalah:

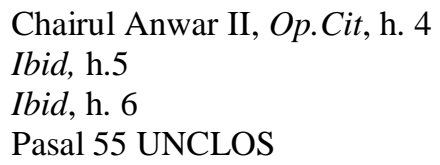


The exclusive economic zone is an area beyond and adjacent to the territorial sea, subyect to the specific legal regime establish in this part, under which the rights and jurisdictionof the coastal state and the rights and freedom of other states are governed by the relevant provision of the convention.

Lebar zona ekonomi eksklusif, ditegaskan dalam pasal 57 UNCLOS sebagai berikut : “

........The exclusive economic zone shall not extend beyond 200 nautical miles from the baselines from which the breadth of the territorial sea is measured".

Berkaitan dengan hak dan kewajiban negara pantai pada zona ekonomi eksklusif tersebut, negara-negara lain juga memiliki hak-hak dan kebebasan-kebebasan yang tidak hanya diatur dalam UNCLOS, namun juga diakui dan dibenarkan oleh Hukum Laut Internasional. Hak-hak dan kebebasan-kebebasan negara lain tersebut misalnya kebebasan pelayaran atau pengoperasian kapal-kapalnya, memasang kabel-kabel dan pipa-pipa saluran di bawah laut atau di dasar laut dan melakukan penerbangan di atasnya.. Berkaitan dengan pelaksanaan hakhak dan kebebasan negara-negara lain tersebut, negara pantai berkewajiban untuk menghormati hak-hak dan kebebasan-kebebasan yang dimiliki oleh negara-negara lain itu, sebaliknya negara-negara lain itupun dalam melaksanakan hak-hak dan kebebasannya juga berkewajiban untuk menghormati hak-hak, kekuasaan dan yurisdiksi serta peraturan perundang-undangan dari negara pantai yang bersangkutan

Berdasarkan pada ketentuan-ketentuan dalam UNCLOS, maka hak-hak dan kewajibankewajiban negara pada zona ekonomi eksklusif di luar perikanan adalah: ${ }^{7}$

\section{a. Hak Memasang Kabel-Kabel Dan Pipa Saluran}

Hak yang dimiliki oleh negara pantai adalah hak untuk memasang kabel-kabel dan pipa-pipa saluran. Yang dimaksudkan hak memasang kabel-kabel dan pipa-pipa saluran tersebut seperti memasang kabel-kabel telepon atau alat komunikasi lainnya, sedangkan pipa saluran, misalnya pipa-pipa yang digunakan untuk menyalurkan minyak dan gas bumi.Hak untuk memasang kabel dan pipa saluran ini adalah hak yang dimiliki oleh semua negara, ${ }^{8}$ sehingga semua negara memiliki hak yang sama untuk memasang kabelkabel dan pipa saluran pada suatu zona ekonomi eksklusif. Pemasangan kabel-kabel dan pipa saluran oleh negara-negara tersebut, dapat dilakukan apabila negara pantai yang bersangkutan memberikan ijin untuk pemasangan atau peletakannya. ${ }^{9}$ Selain itu, apabila pemasangan kabel-kabel dan pipa saluran tersebut memasuki wilayah atau laut teritorial negara pantai, maka negara pantai berhak untuk menetapkan peraturan yang berkenaan dengan pemasangan kabel-kabel dan pipa saluran tersebut. Dengan demikian, negara pantai memiliki yurisdiksi atas kabel-kabel dan pipa saluran yang di bangun oleh negara lain pada zona ekonomi eksklusifnya, tetapi apabila pemasangan kabel-kabel dan pipa saluran oleh negara lain tersebut hanya melewati wilayah laut teritorialnya saja, maka negara pantai tidak memiliki hak untuk mengatur apalagi menghalang-halangi.

P. Joko Subagyo, Hukum Laut Indonesia, Rineka Cipta, Jakarta, 2002, hlm. 71-72

Lihat pasal 79 ayat (1) UNCLOS

Ida Kurnia, Rezim Hukum Landas Kontinen, Diadit Media, Jakarta, 2007, hlm. 30 
b. Hak Membangun Pulau Buatan dan Instalasi-Instalasi

Sebagai kelanjutan dari adanya hak berdaulat untuk melakukan eksplorasi dan eksploitasi adalah adanya kebutuhan negara pantai untuk membangun atau mendirikan pulau buatan dan instalasi-instalasi pada zona ekonomi eksklusif. " Pulau buatan" ini tidak hanya meliputi pulau-pulau buatan dalam arti sebenarnya, tetapi juga termasuk setiap instalasi lainnya untuk maksud eksplorasi dan eksploitasi serta setiap instalasi yang mempengaruhi pelaksanaan hak-hak negara pantai. ${ }^{10}$ Dalam hal ini negara pantai yang membangun atau mendirikan pulau buatan dan instalasi-instalasi tersebut, merupakan konsekuensi logis dari adanya hak berdaulat dari negara pantai tersebut. Pembangunan pulau-pulau buatan dan instalasi-instalasi tersebut merupakan hak negara pantai di zona ekonomi eksklusif. Selain itu negara pantai memiliki yurisdiksi eksklusif atas pulau-pulau buatan dan instalasi yang dibangun oleh negara-negara lain yaitu adanya kewenangan negara pantai untuk mengatur pembangunan pulau buatan dan instalasi yang didirikan di wilayah zona ekonomi eksklusifnya termasuk yurisdiksi yang berkaitan dengan peraturan perundang-undangan bea cukai, fiskal dan lain-lain

Berkaitan dengan pembangunan pulau buatan dan instalasi ini, Churchill mengemukakan :

"In respect of this and the following two right (construction of artificial islands and installations) the Law of the sea convention confers on the coastal state, not " sovereign rights "but the more limited "jurisdiction".

Menurut Churchill negara pantai mempunyai hak atas pulau-pulau buatan dan instalasi, bukan merupakan hak berdaulat melainkan mempunyai yurisdiksi yang terbatas.

Negara pantai selain memiliki hak-hak, terdapat pula kewajiban yang harus dilaksanakan, yaitu :

1) Kewajiban untuk menghormati hak-hak negara lain yang berkaitan dengan pemasangan kabel-kabel dan pipa saluran yang dilakukan oleh negara-negara lain;

2) Kewajiban untuk menghormati kaidah-kaidah hukum internasional, yang berlaitan dengan pelayaran internasional dan penangkapan ikan yang dilakukan oleh negaranegara lain di perairan laut lepas di Zona Ekonomi Ekslusif;

3) Kewajiban untuk menghormati kegiatan eksplorasi dan eksploitasi dari negaranegara lain yang dilakukan berdasarkan atas persetujuan dan ijin dari negara pantai tersebut.

4) Kewajiban untuk selalu menjaga dan melestarikan lingkungan laut dan sumber daya alamnya dari kerusakan dan pencemaran. ${ }^{11}$

10 Albert W Koers, Konvensi Perserikatan Bangsa-Bangsa Tentang Hukum Laut, Suatu Ringkasan, penerjemah Rudi M. Rizki, Wahyuni Bahar, Cet.Kedua, Gadjah Mada University Press, Yogyakarta, 1994, hlm. 41.

11 P. Joko Subagyo, Loc.Cit. 
Adanya hak-hak dan kewajiban yang melekat pada negara pantai tersebut, menandakan bahwa negara pantai tidak dapat sewena-wena menerapkan hukum nasionalnya, kecuali tidak bertentangan dengan hukum internasional

\section{Hak Berdaulat Pada ZEE Indonesia}

Berkaitan dengan hak berdaulat dalam ZEE Indonesia, konsep tentang zona ekonomi eksklusif diawali dengan paham wawasan nusantara yang termuat dalam Deklarasi Djuanda 1957 yang kemudian dituangkan dalam UU No 4/Prp./1960 tentang Perairan, yang menyatakan bahwa Teritorriale Zee en Maritieme Kringen Ordonantie 1939 diganti dengan Wawasaan Nusantara atau Archipelago Principl. Paham ini diperjuangkan dalam berbagai konferensi laut internasional antara lain dalam Konferensi Jenewa tahun 1977. Konferensi ini berhasil menyusun konsep yang dikenal sebagai Informal Compesite Negotiating Text (ICNT). Walaupun bukan persetujuan resmi, namun ICNT menjadi referensi penting dalam perundingan-perundingan selanjutnya mengenai hukum laut. Dalam konferensi itu, telah diakui prinsip wilayah laut territorial yang lebarnya 12 mil ditambah 188 mil Zona Ekonomi, sehingga seluruhnya berjumlah 200 mil dihitung dari garis dasar laut negara bersangkutan. Selanjutnya pengumuman tentang zona ekonomi eksklusif Indonesia dikeluarkan oleh pemerintah Indonesia tanggal 21 Maret 1980.

Berkaitan dengan ZEE yang ada pada UNCLOS, pada pasal 56 menyebutkan bahwa secara umum negara pantai memiliki hak-hak, yurisdiksi dan kewajiban-kewajiban dalam zona ekonomi eksklusif, yaitu :

a. Hak-hak berdaulat (souvereign rights) untuk keperluan eksplorasi dan eksploitasi, konservasi dan pengelolaan sumber daya alam, baik hayati maupun non-hayati dari perairannya.

b. Yurisdiksi-yurisdiksi seperti hal-hal yang berkenaan dengan pembuatan dan pemakaian pulau buatan, instalasi-instalasi dan bangunan-bangunan lainnya, melakukan riset atau penelitian ilmiah kelautan, melakukan perlindungan dan pelestarian lingkungan laut.

c. Hak-hak dan kewajiban-kewajiban lainnya sebagaimana ditentukan di dalam UNCLOS

Sedangkan dalam ketentuan ZEE Indonesia, sebagaimana yang terdapat pada pasal 2 UU No. 5 tahun 1983, menetapkan bahwa. "ZEE Indonesia adalah jalur di luar dan berbatasan dengan laut wilayah Indonesia sebagaimana ditetapkan berdasarkan undang-undang yang berlaku tentang perairan Indonesia yang meliputi dasar laut, tanah dibawahnya dan air diatasnya dengan batas terluar 200 (dua ratus) mil laut diukur dari garis pangkal laut wilayah. Selanjutnya pada pasal 4 tentang Hak Berdaulat, Hak-hak Lain, Yurisdiksi dan Kewajibankewajiban meliputi :

a. Hak berdaulat untuk keperluan eksplorasi dan eksploitasi, konservasi dan pengelolaan sumber kekayaan alam, baik hayati maupun non-hayati.

b. Yurisdiksi, pembuatan pulau-pulau buatan, instalasi, bangunan lainnya, penelitian ilmia, perlindungan dan pelestarian lingkungan laut. 
c. Kewajiban lainnya didasarkan konvensi hukum laut yang berlaku

Selanjutnya pada pasal 5 tentang Kegiatan-kegiatan di ZEE Indonesia disebutkan bahwa

a. Segala kegiatan eksplorasi dan lainnya ada persetujuan dari Internasional tersebut.

b. Segala kegiatan harus berdasarkan ketentuan Pemerintah RI

c. Segala kegiatan eksplorasi dan eksploitasi oleh Negara asing diperbolehkan dengan ijin Pemerintah RI

Berkaitan dengan hak berdaulat sebagaimana yang diuraikan di atas yaitu hak Negara pantai atas ekploitasi, eksplorasi dan konservasi sumber kekayaan laut tersebut, maka berdasarkan hak berdaulat tersebut, Indonesia yang memiliki potensi laut yang sangat luas dapat memanfaatkan dan menikmati sumber kekayan alam laut tersebut dalam rangka menunjang hidup dan kehidupan masyarakat dunia khususnya masyarakat Indonesia demi tercapainya kesejahteraan masyarakat. Sebagaimana kita ketahui bahwa banyak manfaat yang diambil dengan adanya pengaturan tentang ZEE tersebu, yang meliputi dari segi ekonomi sebagai wilayah bebas pelayaran dan jangkauan perdagangan kapal asing dapat dijangkau dan ditampung sebesar-besarnya; dari segi pertahanan sebagai media pertahanan dan keamana wilayah laut sehingga memberi nilai tambah bagi bidang kemiliteran; dan dari segi sosial sebagai tempat mata pencaharianmasyarakat sekitarnyadalam pemenuhan akan kebutuhan potensi biota laut.

Selanjutnya dalam hal pengelolaan sumber daya alam laut disebutkan bahwa Negara wajib mengelola dan melestarikan sumberdaya lautnya, sebagaimana diketaui bahwa Indonesia sangat kaya akan kekayaan mineral seperti minyak dan gas bumi, kerang, rumput laut dan sumberdaya lainnya wajib untuk dikelola sesuai peraturan yang berlaku.

\section{Penutup}

Berdasarkan uraian di atas, maka dapat disimpulkan :

1. Pengaturan hak berdaulat yang terdapat pada UNCLOS pada pasal 56 menyebutkan bahwa secara umum negara pantai memiliki hak-hak, yurisdiksi dan kewajibankewajiban dalam zona ekonomi eksklusif, yaitu hak-hak berdaulat (souvereign rights) untuk keperluan eksplorasi dan eksploitasi, konservasi dan pengelolaan sumber daya alam, baik hayati maupun non-hayati dari perairannya.

2. Adanya pengaturan tentang hak berdaulat dalam peraturan perundang-undangan Indonesia yaitu UU No 5 tahun 1983 yang menyatakan hak Negara pantai atas ekploitasi, eksplorasi dan konservasi sumber kekayaan laut tersebut, maka berdasarkan hak berdaulat tersebut, Indonesia yang memiliki potensi laut yang sangat luas dapat memanfaatkan dan menikmati sumber kekayan alam laut tersebut dalam rangka menunjang hidup dan kehidupan masyarakat dunia khususnya masyarakat Indonesia demi tercapainya kesejahteraan masyarakat. 


\section{Daftar Pustaka}

Albert W Koers, Konvensi Perserikatan Bangsa-Bangsa Tentang Hukum Laut, Suatu Ringkasan, penerjemah Rudi M. Rizki, Wahyuni Bahar, Cet.Kedua, Gadjah Mada University Press, Yogyakarta, 1994

Chairul Anwar, Zona Ekonomi Eksklusif, Dalam Hukum Internasional, Cet pertama, Sinar Grafika, Jakarta, 1995

Ida Kurnia, Rezim Hukum Landas Kontinen, Diadit Media, Jakarta, 2007

P. Joko Subagyo, Hukum Laut Indonesia, Rineka Cipta, Jakarta, 2002

Yusnita Mawarni, Zona Ekonomi Eksklusif, www, academi.edu

Konvensi Hukum Laut ( UNCLOS) 